\title{
Fabrication of Cd(ii) ion-selective membrane electrode based on single walled carbon nanotubes $\mathrm{Ce}(\mathrm{iv})$ phosphate nanocomposite
}

\author{
Tauseef Ahmad Rangreez ${ }^{1 *}$ and Inamuddin ${ }^{2}$ \\ Department of Applied Chemistry, Aligarh Muslim University, Aligarh 202002, India \\ *Email: tauseefjh@gmail.com
}

A single-walled carbon nanotubes cerium(IV) phosphate composite cation exchanger was synthesized using sol gel method[1]. The ionexchange properties such as elution concentration, elution behavior and effect of temperature on ion exchange capacity were studied. The composite cation exchange material showed an ion-exchange capacity (IEC) of 1.64 meq dry $\mathrm{g}^{-1}$ of ion exchanger (Table 1).

Table 1: Conditions of preparation and ionexchange capacity of SWCNT Ce(IV) phosphate

\begin{tabular}{|c|c|c|c|c|c|}
\hline \multirow[t]{2}{*}{ Sample } & \multicolumn{2}{|c|}{$\begin{array}{l}\text { Mixing volume ratios } \\
\text { (V/V) }\end{array}$} & \multirow{2}{*}{$\begin{array}{l}\text { Dispersion of } \\
\text { functionalized } \\
\text { SWVCNTs } \\
\text { (mg) }\end{array}$} & \multirow{2}{*}{$\begin{array}{c}\text { Appearance } \\
\text { of beads after } \\
\text { drying } \\
\text { (color) }\end{array}$} & \multirow[t]{2}{*}{$\begin{array}{c}\mathrm{Na}^{+} \text {IEC } \\
(\text { (meq dry g-1) }\end{array}$} \\
\hline & $\begin{array}{c}0.1 \mathrm{M} \\
\mathrm{CeSO}_{4} .4 \mathrm{H}_{2} \mathrm{O} \\
\text { in } 0.5 \mathrm{M} \\
\mathrm{H}_{2} \mathrm{SO}_{4}\end{array}$ & $\begin{array}{c}6 \mathrm{M} \\
\mathrm{H}_{3} \mathrm{PO}_{4}\end{array}$ & & & \\
\hline S-1 & 1 & 1.0 & 0 & White & 1.20 \\
\hline S-2 & 1 & 1.5 & 0 & White & 1.20 \\
\hline S-3 & 1 & 2.0 & 0 & White & 1.20 \\
\hline S-4 & 1 & 1.0 & 50 & Grey & 1.42 \\
\hline S-5 & 1 & 1.0 & 100 & Grey & 1.53 \\
\hline S-6 & 1 & 1.0 & 150 & Grey & 1.64 \\
\hline S-7 & 1 & 1.0 & 200 & Grey & 1.64 \\
\hline
\end{tabular}

The distribution studies [2] revealed that the composite cation exchanger is highly selective for $\mathrm{Cd}(\mathrm{II})$ ions. A $\mathrm{Cd}(\mathrm{II})$ ion-selective membrane electrode based on single walled carbon nanotubes $\mathrm{Ce}(\mathrm{IV})$ phosphate has fabricated using solution casting method[3]. The membrane with $300 \mathrm{mg}$ of single walled carbon nanotubes $\mathrm{Ce}(\mathrm{IV})$ phosphate and $10 \mu \mathrm{L}$ of plasticiser exhibited highest proton conductivity. The membrane electrode showed a Nernstian response for $\mathrm{Cd}(\mathrm{II})$ ions over a wide concentration range of $1 \times 10^{-1}$ to $1 \times 10^{-7} \mathrm{M}$ and exhibited a sub-Nernstian slope of $27.42 \mathrm{mV}$ per decade change in concentration of cadmium ions (Figure 1). The limit of detection was found to be $1 \times 10^{-7} \mathrm{M}$.

The fabricated membrane electrode exhibits a fast response time (10 s) and can be utilized for
130 days without any considerable divergence in response potential. The effect of interference of various metal ions on the selectivity of electrode towards $\mathrm{Cd}(\mathrm{II})$ ions was also examined in order to demonstrate the utility of proposed electrode in the presence of other ionic species. The practical utility of the membrane electrode was demonstrated by employing it as an indicator electrode for the estimation of $\mathrm{Cd}(\mathrm{II})$ by the potentiometric titration with ethylenediamine tetraacetic acid, disodium salt.

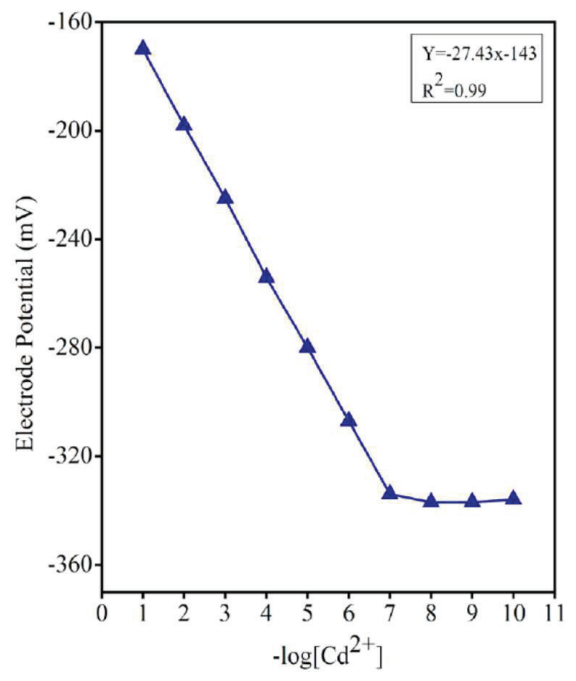

Figure 1: Calibration curve for $\mathrm{Cd}^{2+}$ ion-selective membrane electrode

\section{References}

1. Inamuddin, T. A. Rangreez, A. Khan, POLYMER COMPOSITES, DOI 10.1002/pc.23664.

2. S.A. Nabi, R. Bushra, M. Shahadat, JOURNAL OF APPLIED POLYMER SCIENCE, DOI 10.1002/app.36325.

3. Inamuddin, A. Khan, M. Luqman, A. Dutta, Sensors and Actuators A 216 (2014) 295-300. 